\title{
sciendo
}

\section{YUCCA SCHIDIGERA EXTRACT DIETARY SUPPLEMENTATION AFFECTS GROWTH PERFORMANCE, HEMATOLOGICAL AND PHYSIOLOGICAL STATUS OF EUROPEAN SEABASS}

\author{
Abdallah Tageldein Mansour ${ }^{1,2 \bullet}$, Walied Mohamed Fayed ${ }^{2}$, Bassem Khalil Elkhayat ${ }^{2}$, Eglal Ali Omar ${ }^{2}$, \\ Mohamed A. Zaki ${ }^{3}$, Abdel-Aziz Moussa Nour ${ }^{3}$, Sabrin Abdelrahman Morshedy ${ }^{2 *}$ \\ ${ }^{1}$ Animal and Fish Production Department, College of Agricultural and Food Sciences, King Faisal \\ University, P.O. Box 420, Al-Ahsa 31982, Kingdom of Saudi Arabia \\ ${ }^{2}$ Department of Fish and Animal Production, Faculty of Agriculture (Saba Basha), P.O. Box 21531, \\ Alexandria University, Egypt \\ ${ }^{3}$ Department of Fish and Animal Production, Faculty of Agriculture (El-Shatby), Alexandria University, \\ Egypt \\ •Corresponding author: amansour@kfu.edu.sa; sabrin_morshedy@alexu.edu.eg
}

\begin{abstract}
The study herein evaluated the effects of dietary supplementation with different yucca (Yucca schidigera) extract levels on rearing water quality, growth performance, protein utilization, hematological and immunological status, and economic benefits of cultured European seabass (Dicentrarchus labrax) juveniles. Yucca extract (YE) was incorporated in an experimental diet at levels of $0,0.25,0.50$, and $1 \mathrm{~g} \mathrm{YE} \mathrm{kg}^{-1}$, and offered to fish reared in $70-\mathrm{L}$ glass aquaria (15 fish per aquarium; three replicates each). Dietary YE supplementation significantly $(\mathrm{P}<0.05)$ decreased ammonia-nitrogen levels in water. Compared with the control, groups fed 0.50 and $1 \mathrm{~g} \mathrm{YE} \mathrm{kg}^{-1}$ diets showed improved growth performance (by $26.02 \%$ and $36.98 \%$, respectively) and protein efficiency ratio (by $31.39 \%$ and $37.29 \%$, respectively). In addition, hematological parameters (red blood cells, hemoglobin, hematocrit, white blood cells and neutrophil) and innate immune parameters (globulin fractions and lysozyme activity) improved with increasing dietary YE levels. Growth, hematological, and immunological parameters increased with a polynomial second-order regression models, with curves peak close to $1 \mathrm{~g} \mathrm{YE} \mathrm{kg}^{-1}$ diet. The cortisol level decreased significantly $(\mathrm{P}<0.05)$ with increasing dietary $\mathrm{YE}$ levels. The groups fed the 0.50 and $1 \mathrm{~g} \mathrm{YE} \mathrm{kg}^{-1}$ diets generated significantly $(\mathrm{P}<0.05)$ higher revenue than groups fed the $0.25 \mathrm{~g} \mathrm{YE} \mathrm{kg}^{-1}$ and the control diets. The using of $\mathrm{YE}$ is recommended as a dietary feed additive at a level of $1 \mathrm{~g} \mathrm{~kg}^{-1}$ for reducing the environmental footprint of fish protein production, accelerating growth, and improving health status of cultured seabass in a short-term feeding period.
\end{abstract}

Key words: Dicentrarchus labrax, growth performance, hematological, immunological status, water quality, Yucca schidigera extract 
European seabass (Dicentrarchus labrax) is one of the economically important marine fish species in temperate areas, including the Mediterranean Sea, the Black Sea, and the Atlantic coastline from Norway to Morocco (Eroldogan et al., 2004; Altan and Korkut, 2010). In Egypt, European seabass production is second to gilthead sea bream, the estimated yield is 30720 tons with the expectation to be duplicated in near future due to intensive culture (GAFRD, 2017). Intensification of fish farming is the best way in the aquaculture industry to meet the human demand for protein and reduce the pressure on natural fishery resources (Aubin et al., 2019). However, with the intensification of aquaculture, both consumed feed and excreted nitrogen will increase, which may affect fish metabolism and ambient water bodies (Besson et al., 2016; Aubin et al., 2019). Therefore, the improvement of protein metabolism and subsequent reduction of nitrogen excretion are crucial for sustainable development in this sector (Kelly and Kohler, 2003). Natural feed additives such as phytogenics are suitable for cleaner production (Adegbeye et al., 2019) and improving growth, feed utilization, general physiology, and disease resistance of cultured fish (Mansour et al., 2017; Acar, 2018; Mansour et al., 2018 b; Acar et al., 2019).

Yucca schidigera (Mojave yucca) grows in the deserts of southwestern USA and Mexico (Tenon et al., 2017). The ability of yucca to grow in arid regions with high temperature and low water availability maximizes its potential use as a future sustainable feed additive, particularly in the regions that are likely to experience a new dimension of global warming (Adegbeye et al., 2019). The commercial products of $Y$. schidigera, including yucca powder which is dry powder of yucca trunk and yucca extract which is concentrated juice produced by mechanical squeezing of plant logs are approved for human use by the FDA (Piacente et al., 2005). Yucca extract (YE) is a rich source of steroidal saponins, resveratrol and polyphenolics (Ayasan et al., 2005; Tenon et al., 2017).

The extract of yucca has been used in the aquaculture, poultry, and livestock industries, primarily to mitigate pollution by minimizing ammonia excretion and methane emission (Headon and Dawson, 1990; Hristov et al., 1999; Sarkar, 1999; El-Saidy and Gaber, 2004). Direct application of yucca to both fresh- and saltwater aquatic rearing systems reduced ammonia levels in a dose-dependent manner (Santacruz-Reyes and Chien, 2010; Khalil et al., 2015; Fayed et al., 2019). In addition, YE enhanced protein metabolism, reduced ammonia excretion, and improved growth performance of different fish species (Kelly and Kohler, 2003; El-Saidy and Gaber, 2004; Gaber, 2006; Güroy et al., 2014; Fayed et al., 2019).

The potential effect of YE on controlling ammonia levels relies on its content of steroidal saponin fractions, which have surface active properties and can bind to ammonia via glycol-component fractions (Cheeke, 2000). Moreover, YE can be absorbed and enter the blood stream (Yang et al., 2015; Hassan et al., 2017). The systemic effect of YE in the animal body is varied, whereas it has anti-inflammatory (Cheeke, 2000), immunostimulatory, antioxidant (Su et al., 2016), antistress (Cigerci et al., 2009; Ince et al., 2013), antiviral and antitumor effects (Piacente et al., 2005). Moreover, YE can contribute to the regulation of energy metabolism and hormonal activity in animals, and the treatment of nutritional disorders (Kucukkurt et al., 2016). The YE has been firstly used for environmental considerations of controlling 
global warming greenhouse gases, however it also has several desirable biological effects in the animal body (Adegbeye et al., 2019). Taking this previous knowledge into consideration, the present study was designed to investigate and evaluate the effectiveness of dietary supplementation of YE on water quality, zootechnical performance, protein utilization, hematological and immunological status, cortisol level, and economic revenue in cultured European seabass, D. labrax, juveniles.

\section{Material and methods}

\section{Fish and experimental facilities}

A total of 180 apparently healthy D. labrax fingerlings with an average body weight of $5.0 \pm 0.5 \mathrm{~g}$ were used. The feeding experiments were performed in an indoor wet laboratory at El-Shreif Fish Farm and Hatchery (Mariuot valley, Alexandria, Egypt). Prior to starting the experiments, the fish were acclimated to the experimental conditions for 2 weeks in four indoor circular fiberglass tanks $\left(1 \mathrm{~m}^{3}\right)$ and were fed the control basal diet (Table 1).

The fish were randomly divided into 12 glass aquaria $\left(70 \times 40 \times 30 \mathrm{~cm}^{3} ; \sim 70 \mathrm{~L}\right.$ each; 15 fish per aquarium), representing four experimental treatments (three replicates per treatment). Each aquarium was supported with artificial aeration through an air blower and 5-cm sandstone. The water source was groundwater of a saline water well, with $32 \%$ salinity and $\mathrm{pH}(7.0 \pm 0.5)$. Throughout the experimental period, the lighting regime was a 12:12-h light: dark cycle and the dissolved oxygen (DO) level was $6.01 \pm 0.2 \mathrm{mg} \mathrm{L}^{-1}$. Fish excreta were removed by manual siphoning, and the water exchange rate was 30\% per day. The Institutional Animal Care and Use Committee of Alexandria University have approved the fish care used in the present study.

\section{Experimental design and diets}

Fish in the four experimental treatments were fed one of the following isonitrogenous ( $\sim 45 \%$ crude protein) and isocaloric $\left(\sim 20.32 \mathrm{MJ} \mathrm{kg}^{-1}\right)$ diets (Table 1) as follows: (1) control diet without any YE supplementation ( $\left.\mathrm{YE}_{0}\right)$; (2) experimental diet supplemented with $0.25 \mathrm{~g} \mathrm{YE} \mathrm{kg}^{-1}\left(\mathrm{YE}_{0.25}\right)$; (3) experimental diet supplemented with $0.5 \mathrm{~g} \mathrm{YE} \mathrm{kg}^{-1}\left(\mathrm{YE}_{0.5}\right)$; and (4) experimental diet supplemented with $1 \mathrm{~g} \mathrm{YE} \mathrm{kg}^{-1}$ $\left(\mathrm{YE}_{1}\right)$ (Table 1). The YE levels were selected according to previous studies (Kelly and Kohler, 2003; Gaber, 2006). The experiment lasted 45 days.

The fish were fed the experimental diets to apparent satiation two times daily (9:00 a.m. and 2:00 p.m.). Apparent satiation was considered to have occurred $30 \mathrm{~min}$ after introduction of the diet, after which the remaining pellets were collected, dried, and weighed for accurate determination of actual feed intake. The diets were prepared by finely grinding solid ingredients to powder and manually mixing in a plastic container for $\sim 15$ min to ensure homogeneity. Oil and additives were slowly added to the mixture. Warm distilled water was gradually added until the diet began to clump and form a dough-like paste, which was then passed through a commercial meat grinder to form a spaghetti-like prepared diet $(0.3 \mathrm{~mm}$ in diameter). The result- 
ant pellets were dried in a forced-air drying oven at $40-45^{\circ} \mathrm{C}$ to a moisture level of $<10 \%$ and stored at $-20^{\circ} \mathrm{C}$ until further use.

The proximate chemical composition (\%) of the formulated diets was analyzed (AOAC, 2000) and presented in Table 1.

\section{Measured parameters}

Water quality parameters

Water quality parameters were determined according to the standard guidelines (A.P.H.A., 1998). Dissolved oxygen was measured with a digital oxygen meter (HI9142, Hanna Instruments, US), temperature, and $\mathrm{pH}$ were measured with a digital pH meter (Research Model 211 Digital pH Meter, Hanna Instruments, US). Salinity was measured with a salinity meter (YSI EcoSense EC300 Conductivity/Salinity 151, US). Total ammonia levels were measured with a portable digital multi-meter (Crison Model MM41, Spain) and were daily recorded (at 12:30 p.m.) for all aquaria throughout the experiment. Non-ionized ammonia $\left(\mathrm{NH}_{3}\right)$ levels were calculated as the percentage of total ammonia based on water temperature and $\mathrm{pH}$ according to the US Environmental Protection Agency (EPA) guidelines (U.S. EPA, 1989).

\section{Growth performance and survival}

Mean final body weight (FBW) in each experimental treatment was determined by dividing the total fish weight in each aquarium by the number of fish. Weight gain (WG), specific growth rate (SGR), and survival (\%) were calculated using the following equations (Castell and Tiewes, 1980):

where:

$$
W G\left(g f i s h^{-1}\right)=W_{2}-W_{1}
$$

$W_{1}$ is the initial weight of the fish $(\mathrm{g})$ and $W_{2}$ is FBW of the fish $(\mathrm{g})$.

where:

$$
\operatorname{SGR}\left(\% d a y^{-1}\right)=100 \times\left(\ln W_{2}-\ln W_{1}\right) / \text { days }
$$

$\ln$ is the natural $\log$.

Survival $(\%)=100 \times$ (the final number of the fish/initial number of the fish).

Table 1. Ingredients and chemical composition (on dry matter basis) of the experimental diets

\begin{tabular}{l|c|c|c|c}
\hline \multirow{2}{*}{\multicolumn{1}{c}{ Ingredients (\%) }} & \multicolumn{4}{c}{ Yucca extract levels ( $\left.\mathrm{g} \mathrm{kg}^{-1}\right)$} \\
\cline { 2 - 5 } \multicolumn{1}{c|}{1} & 0.0 & 0.25 & 0.50 & 1.00 \\
\hline Fish meal (68\% CP) & 2 & 3 & 4 & 5 \\
Soybean meal (47\% CP) & 30.00 & 30.00 & 30.00 & 30.00 \\
Corn gluten (60\% CP) & 37.50 & 37.50 & 37.50 & 37.50 \\
Rice bran (12\% CP) & 9.00 & 9.00 & 9.00 & 9.00 \\
Wheat middling (13\% CP) & 6.50 & 6.50 & 6.50 & 6.50 \\
Soybean oil & 7.10 & 7.08 & 7.05 & 7.00 \\
\hline
\end{tabular}


Table 1 - contd.

\begin{tabular}{lcc|c|c}
\hline \multicolumn{1}{c|}{1} & 2 & 3 & 4 & \multicolumn{1}{c}{5} \\
\hline Fish oil & 4.88 & 4.88 & 4.88 & 4.88 \\
Dicalcium phosphate & 0.80 & 0.80 & 0.80 & 0.80 \\
Vitamins and minerals mixture* & 0.20 & 0.20 & 0.20 & 0.20 \\
Vitamin C & 0.02 & 0.02 & 0.02 & 0.02 \\
Yucca, Yucca schidigera, extract ${ }^{*}$ & 0.00 & 0.025 & 0.050 & 0.10 \\
Chemical composition (g 100 g-1 DM) & & & & \\
Dry matter (DM) & 93.80 & 93.75 & 93.18 & 93.77 \\
Crude protein (CP) & 44.86 & 44.88 & 44.97 & 44.60 \\
Ether extract (EE) & 12.56 & 13.10 & 12.98 & 12.89 \\
Nitrogen free extract (NFE) $\dagger$ & 28.34 & 25.70 & 26.65 & 27.86 \\
Crude fiber (CF) & 3.24 & 3.32 & 3.40 & 3.20 \\
Ash & 11.00 & 12.00 & 12.00 & 11.45 \\
Gross energy (GE; $\left.\mathrm{MJ} \mathrm{kg}^{-1} \mathrm{DM}\right)+$ & 20.41 & 20.17 & 20.31 & 20.39 \\
\hline
\end{tabular}

*Composition of vitamins and minerals mixture for $1 \mathrm{~kg}$ : Vitamin A: 5,000,000 IU; vitamin $\mathrm{D}_{3}: 10,000,000$ $\mathrm{IU}$; vitamin $\mathrm{B}_{2}: 2.0 \mathrm{~g}$; vitamin $\mathrm{E}: 750 \mathrm{U}$; vitamin $\mathrm{K}: 1.0 \mathrm{~g}$; calcium pantothenate: $2.5 \mathrm{~g}$; nicotinamide: $10.0 \mathrm{~g}$; vitamin $\mathrm{B}_{12}: 6.0 \mathrm{~g}$; choline chloride: $150.0 \mathrm{~g}$; manganese sulphate anhydrous: $27.5 \mathrm{~g}$; potassium iodide: $1.0 \mathrm{~g}$; ferrous sulphate: $7.5 \mathrm{~g}$; zinc sulphate heptahydrate: $15.0 \mathrm{~g}$; copper sulphate: $2.0 \mathrm{~g}$; sodium selenite, $0.1 \mathrm{~g}$; cobalt chloride: $0.45 \mathrm{~g}$; and calcium carbonate: up to $1000 \mathrm{~g}$.

${ }^{¥}$ Yucca (Yucca schidigera) extract: Vime-Yucca (P) ${ }^{\circledR}$ containing $33 \%$ yucca extract with $12 \%$ saponin, produced by Vemedim Corporation, Vietnam.

'NFE: Nitrogen-free extract calculated using the following equation: NFE $=100-$ (crude protein + ether extract + crude fiber + ash) (National Research Council, 2011).

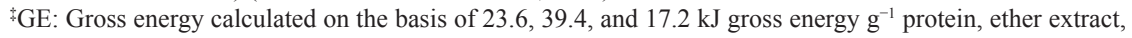
and NFE, respectively (National Research Council, 2011).

\section{Feed and protein utilization}

Feed intake for each group was calculated by dividing the total feed intake (g) of the group by the number of fish in that group. Feed conversion ratio (FCR) and protein efficiency ratio (PER) were calculated as follows:

$$
\begin{gathered}
F C R=\text { feed intake }(g) / \text { weight gain }(g) \\
\text { PER }=\text { weight gain }(g) / \text { protein intake }(g)
\end{gathered}
$$

\section{Hematological and immunological parameters}

At the end of the experiment, the fish were anesthetized with clove oil $\left(50 \mathrm{mg} \mathrm{L}^{-1}\right)$ and blood samples were collected from 10 fish per aquarium using sterile, disposable 1-ml syringes containing $50 \mu \mathrm{L}$ heparin ( $\mathrm{IU} \mathrm{mL}^{-1}$, Amoun Pharmaceutical Co. S.A.E., Egypt). The collected blood was divided into two tubes; the first was used for hematological assays and the second was centrifuged $(1075 \times \mathrm{g}, 5 \mathrm{~min})$ to obtain the plasma. The plasma samples were stored at $-80^{\circ} \mathrm{C}$ until being used for biochemical and immunological assays.

Total red and white blood cell counts $\left(\mathrm{RBC}, 10^{6} \mathrm{~mm}^{-3}\right.$ and $\mathrm{WBC}, 10^{3} \mathrm{~mm}^{-3}$, respectively) were determined using a standard Neubauer hemocytometer with Shaw's solution as a diluent. Hematocrit (Ht; \%) was determined by filling hematocrit cap- 
illary tubes, which were centrifuged $(8400 \times \mathrm{g}, 10 \mathrm{~min})$ in a microhematocrit centrifuge (Krebs, Bunsen, EU). Hematocrit values were recorded using a centrifuge combo-reader. Hemoglobin level $\left(\mathrm{Hb} ; \mathrm{g} \mathrm{dL}^{-1}\right)$ was determined colorimetrically using commercial kits (Diamond, Egypt) according to the cyanmethemoglobin method (Van-Kampen and Zijlstra, 1961). The differential leukocyte count was determined by observing Giemsa-stained smears through light microscopy at 100x magnification (B-293 LD 1.50, Optika, Via Rigla, Ponteranica, Italy).

Total plasma protein level ( $\mathrm{g} \mathrm{dL}^{-1}$ ) was determined using the biuret method (Gornal et al., 1949). Albumin level ( $\left.\mathrm{g} \mathrm{dL}^{-1}\right)$ was determined using the bromocresol green method (Reinhold, 1953), and globulin level $\left(\mathrm{g} \mathrm{dL}^{-1}\right)$ was calculated as the difference between total protein and albumin levels. Globulin fractions were determined in plasma samples using capillary zone electrophoresis (Ihara et al., 2001).

Plasma lysozyme activity ( $\mathrm{U} \mathrm{mg}^{-1}$ protein) was determined using turbidimetric assay (Swain et al., 2007). Briefly, $20 \mu \mathrm{L}$ of plasma was placed in 96-well flat-bottomed plates with $180 \mu \mathrm{L}$ of freeze-dried Micrococcus lysodeikticus $\left(0.2 \mathrm{mg} \mathrm{mL}^{-1}\right.$, Sigma-Aldrich) in $40 \mathrm{mM}$ sodium phosphate ( $\mathrm{pH} \mathrm{6.2).} \mathrm{As} \mathrm{blanks} \mathrm{of} \mathrm{each} \mathrm{sample,}$ $20 \mu \mathrm{L}$ of plasma was added to $180 \mu \mathrm{L}$ of sodium phosphate buffer. The OD was measured at $450 \mathrm{~nm}$ after $20 \mathrm{~min}$ at $35^{\circ} \mathrm{C}$ in a microplate reader. The amounts of lysozyme present in plasma were obtained from a standard curve made with hen egg white lysozyme (HEWL, Sigma). Cortisol level (pg $\mathrm{mL}^{-1}$ ) was determined using a commercial ELISA kit based on manufacturer instructions (IBL ${ }^{\circledR}$, Germany) (Gomez-Sanchez et al., 1977).

\section{Economic evaluation}

A simple economic evaluation was done by calculating the cost of the feed in Egyptian pounds (LE) needed to produce $1 \mathrm{~kg}$ live weight of fish. Additionally, the cost of protein production was calculated as follows:

$$
\text { Feed cost } *\left(\mathrm{~kg}^{-1} \mathrm{WG}\right)=\mathrm{FCR} \times \text { cost } \mathrm{kg}^{-1} \text { feed }
$$

*The costs of feed ingredients were as follows: fishmeal: LE 19, soybean meal: LE 5.8, corn gluten (60\%): LE 8, rice bran: LE 1.8, wheat middling: LE 2.3, soybean oil: LE 14, herring oil: LE 16, vitamins: LE 18, dicalcium phosphate: LE 4.8, and YE [Vime-Yucca (P $)^{\circledR}$ ]: LE 300. 1 US \$=17.68 LE at the time of calculation.

\section{Statistical analysis}

All data were subjected to one-way analysis of variance and when a significant difference was found among treatments $(\mathrm{P} \leq 0.05)$. Duncan's multiple range test was performed to rank the groups (Duncan, 1955) using SPSS (Standard Version 17.0 SPSS Inc. Chicago, Illinois). The associations of YE supplementation levels with specific growth, hematological and immunological parameters were investigated to determine the fit of regression models and the optimum dietary level of YE was identified using GraphPad Prism version 7.00 for Windows, GraphPad Software, La Jolla California USA. 


\section{Results}

\section{Water quality parameters}

The water quality parameters of aquaria harboring D. labrax fingerlings fed diets supplemented with different levels of YE are illustrated in Table 2 and Figure 1. Increasing YE supplementation level significantly decreased levels of total ammonia nitrogen as well as ionized and unionized ammonia nitrogen in a dose-dependent manner. However, $\mathrm{DO}$ and $\mathrm{pH}$ did not differ significantly across treatments.

Table 2. Water quality parameters of European seabass (Dicentrarchus labrax) fingerlings fed diets supplemented with different levels of Yucca schidigera extract ( $\mathrm{g} \mathrm{kg}^{-1}$ diet); average salinity: $32 \mathrm{ppt}$; temperature: $28 \pm 1.0^{\circ} \mathrm{C}$

\begin{tabular}{l|c|c|c|c}
\hline \multirow{2}{*}{\multicolumn{1}{c|}{ Treatments }} & \multicolumn{4}{c}{ Yucca extract levels $\left(\mathrm{g} \mathrm{kg}^{-1}\right)$} \\
\cline { 2 - 5 } & 0.0 & 0.25 & 0.50 & 1.00 \\
\hline $\mathrm{pH}$ & $7.54 \pm 0.29$ & $7.63 \pm 0.17$ & $7.55 \pm 0.58$ & $7.88 \pm 0.26$ \\
Dissolved oxygen $\left(\mathrm{mg} \mathrm{L}^{-1}\right)$ & $5.41 \pm 0.23$ & $5.54 \pm 0.07$ & $5.81 \pm 0.18$ & $5.28 \pm 0.18$ \\
Total-ammonia nitrogen (mg L-1) & $1.06 \pm 0.07 \mathrm{a}$ & $1.13 \pm 0.07 \mathrm{a}$ & $0.81 \pm 0.01 \mathrm{~b}$ & $0.37 \pm 0.10 \mathrm{c}$ \\
$\mathrm{NH}_{4}-\mathrm{N}\left(\mathrm{mg} \mathrm{L}^{-1}\right)$ & $0.83 \pm 0.05 \mathrm{a}$ & $0.73 \pm 0.01 \mathrm{~b}$ & $0.41 \pm 0.01 \mathrm{c}$ & $0.07 \pm 0.01 \mathrm{~d}$ \\
$\mathrm{NH}_{3}-\mathrm{N}\left(\mathrm{mg} \mathrm{L}^{-1}\right)$ & $0.019 \pm 0.001 \mathrm{a}$ & $0.021 \pm 0.001 \mathrm{a}$ & $0.011 \pm 0.001 \mathrm{~b}$ & $0.005 \pm 0.01 \mathrm{c}$ \\
\hline
\end{tabular}

Means in the same row bearing different letters differ significantly $(\mathrm{P} \leq 0.05)$.
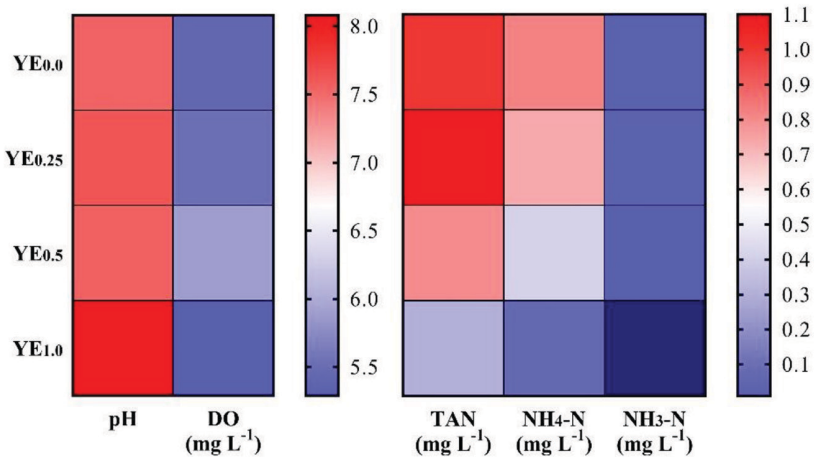

Figure 1. Heatmap of aquarium water quality changes with dietary supplementation of Yucca schidigera extract ( $\mathrm{g} \mathrm{kg}^{-1}$ diet) in European seabass (Dicentrarchus labrax) fingerlings diets

\section{Growth performance}

Growth performance data of D. labrax fed different dietary levels of YE are presented in Table 3 and Figure 2 A. Final body weight was significantly increased with $\mathrm{YE}_{0.5}$ and $\mathrm{YE}_{1}$ compared to that with control $\left(\mathrm{YE}_{0}\right)$. Moreover, WG and SGR were significantly improved with all YE-supplemented diets in a quadratic regression fit model. Moreover, no mortality was reported during the experimental period.

\section{Feed and protein utilization}

The effects of YE supplementation on feed intake and protein utilization are illustrated in Table 3 and Figure 2 B. Feed intake did not significantly differ across 
treatments. Meanwhile, FCR was significantly improved with increasing YE supplementation levels compared to that with control in a polynomial second-order regression model. Protein efficiency ratio was significantly increased with higher supplementation levels of YE $\left(0.5\right.$ and $\left.1 \mathrm{~g} \mathrm{~kg}^{-1}\right)$ compared to that with control.

Table 3. Growth performance and survival of European seabass (Dicentrarchus labrax) fed diets supplemented with different levels of Yucca schidigera extract $\left(\mathrm{g} \mathrm{kg}^{-1}\right)(\mathrm{n}=3$; mean $\pm \mathrm{SE})$

\begin{tabular}{l|c|c|c|c}
\hline \multirow{2}{*}{\multicolumn{1}{c}{ Treatments }} & \multicolumn{4}{c}{ Yucca extract levels $\left(\mathrm{g} \mathrm{kg}^{-1}\right)$} \\
\cline { 2 - 5 } & 0.00 & 0.25 & 0.50 & 1.00 \\
\hline Initial weight $\left(\mathrm{g} \mathrm{fish}^{-1}\right)$ & $5.53 \pm 0.09$ & $5.30 \pm 0.06$ & $5.43 \pm 0.09$ & $5.43 \pm 0.15$ \\
Final body weight $\left(\mathrm{g} \mathrm{fish}^{-1}\right)$ & $12.87 \pm 0.22 \mathrm{c}$ & $13.92 \pm 0.27 \mathrm{c}$ & $16.22 \pm 0.41 \mathrm{~b}$ & $17.63 \pm 0.42 \mathrm{a}$ \\
Weight gain $\left(\mathrm{g} \mathrm{fish}^{-1}\right)$ & $7.34 \pm 0.13 \mathrm{~d}$ & $8.62 \pm 0.22 \mathrm{c}$ & $10.78 \pm 0.49 \mathrm{~b}$ & $12.20 \pm 0.28 \mathrm{a}$ \\
Specific growth rate $\left(\%\right.$ day $\left.^{-1}\right)$ & $2.52 \pm 0.02 \mathrm{~d}$ & $2.60 \pm 0.02 \mathrm{c}$ & $2.75 \pm 0.03 \mathrm{~b}$ & $2.83 \pm 0.02 \mathrm{a}$ \\
Survival $(\%)$ & $100 \pm 00$ & $100 \pm 00$ & $100 \pm 00$ & $100 \pm 00$ \\
Feed intake $\left(\mathrm{g} \mathrm{fish}^{-1}\right)$ & $11.97 \pm 0.99$ & $14.17 \pm 1.59$ & $13.30 \pm 0.10$ & $13.20 \pm 0.60$ \\
Feed conversion ratio & $1.63 \pm 0.03 \mathrm{a}$ & $1.65 \pm 0.04 \mathrm{a}$ & $1.24 \pm 0.06 \mathrm{~d}$ & $1.08 \pm 0.02 \mathrm{c}$ \\
Protein efficiency ratio & $1.37 \pm 0.02 \mathrm{c}$ & $1.36 \pm 0.04 \mathrm{c}$ & $1.80 \pm 0.08 \mathrm{~b}$ & $2.07 \pm 0.05 \mathrm{a}$ \\
\hline
\end{tabular}

Means in the same row bearing different letters differ significantly $(\mathrm{P} \leq 0.05)$.
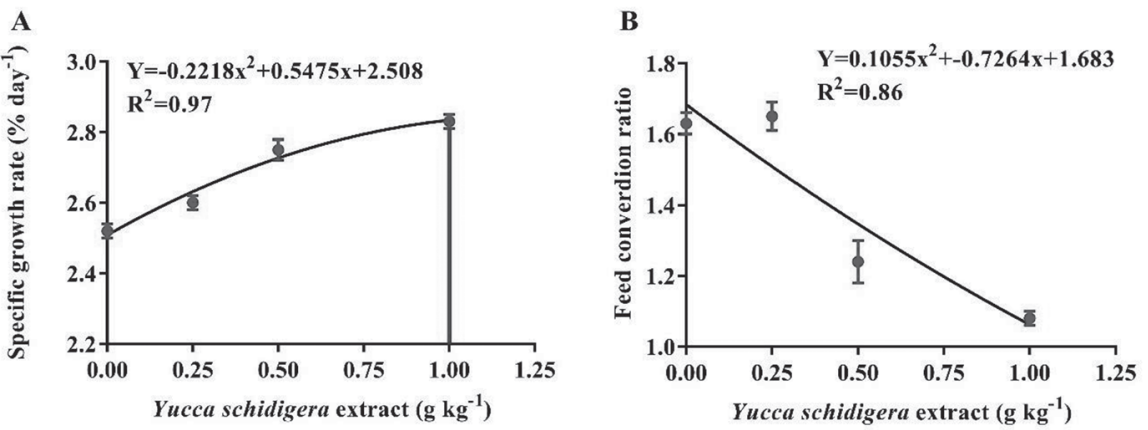

Figure 2. Polynomial second-order regression curve of specific growth rate and feed conversion ratio of European seabass (Dicentrarchus labrax) fingerlings fed diets supplemented with Yucca schidigera extract $\left(\mathrm{g} \mathrm{kg}^{-1}\right)$

Table 4. Hematological parameters of European seabass (Dicentrarchus labrax) fed diets supplemented with different levels of Yucca schidigera extract $\left(\mathrm{g} \mathrm{kg}^{-1}\right)(\mathrm{n}=3$; mean $\pm \mathrm{SE})$

\begin{tabular}{l|c|c|c|c}
\hline \multirow{2}{*}{\multicolumn{1}{c}{ Treatments }} & \multicolumn{4}{c}{ Yucca extract levels $\left(\mathrm{g} \mathrm{kg}^{-1}\right)$} \\
\cline { 2 - 5 } & 0.0 & 0.25 & 0.50 & 1.00 \\
\hline Red blood cells $\left(10^{6} \mathrm{~mm}^{-3}\right)$ & $1.62 \pm 0.22 \mathrm{~b}$ & $2.14 \pm 0.32 \mathrm{~b}$ & $2.94 \pm 0.43 \mathrm{a}$ & $2.97 \pm 0.37 \mathrm{a}$ \\
Hematocrit (\%) & $25.08 \pm 1.15 \mathrm{~b}$ & $26.19 \pm 1.26 \mathrm{~b}$ & $31.12 \pm 1.35 \mathrm{a}$ & $29.33 \pm 1.31 \mathrm{a}$ \\
Hemoglobin $\left(\mathrm{g} \mathrm{dl}^{-1}\right)$ & $7.23 \pm 0.72 \mathrm{~b}$ & $8.86 \pm 0.72 \mathrm{~b}$ & $11.62 \pm 0.89 \mathrm{a}$ & $11.39 \pm 0.85 \mathrm{a}$ \\
White blood cells $\left(10^{3} \mathrm{~mm}^{-3}\right)$ & $24.33 \pm 1.31 \mathrm{c}$ & $31.67 \pm 1.37 \mathrm{~b}$ & $41.11 \pm 1.69 \mathrm{a}$ & $37.18 \pm 1.64 \mathrm{a}$ \\
Lymphocyte (\%) & $35.33 \pm 2.03$ & $35.67 \pm 2.08$ & $38.33 \pm 2.09$ & $39.33 \pm 2.09$ \\
Monocyte (\%) & $2.67 \pm 0.33$ & $2.00 \pm 0.58$ & $2.50 \pm 0.33$ & $2.97 \pm 0.33$ \\
Neutrophil (\%) & $40.67 \pm 2.91 \mathrm{c}$ & $41.67 \pm 2.91 \mathrm{bc}$ & $49.67 \pm 1.76 \mathrm{ab}$ & $52.67 \pm 2.91 \mathrm{a}$ \\
\hline
\end{tabular}

Means in the same row bearing different letters differ significantly $(\mathrm{P} \leq 0.05)$. 


\section{Hematological parameters}

The results of hematological examination showed a significant increase in $\mathrm{RBC}, \mathrm{Hb}, \mathrm{Ht}$, and WBC values with the highest level of YE supplementation (Table 4). Furthermore, WBC differential showed a significant increase in neutrophil count $(\%)$ with increasing YE supplementation level (Table 4). However, lymphocyte and monocyte (\%) counts were not significantly affected by YE supplementation. In the polynomial second-order regression model of increasing YE level, the highest $\mathrm{Ht}$ and $\mathrm{WBC}$ values were 0.72 and 0.69 , respectively (Figure $3 \mathrm{~A}$ and B).

\section{Immunological parameters}

Total protein, globulin, and globulin fraction (alpha, beta, and gamma globulin) values were markedly increased with increasing YE supplementation levels. In addition, albumin level and lysozyme activity increased with $\mathrm{YE}_{0.5}$ and $\mathrm{YE}_{1}$ (Table 5). The association of YE supplementation level with globulin level and lysozyme activity showed a polynomial second-order regression curve, with peak lysozyme activity at $0.82 \mathrm{~g} \mathrm{YE} \mathrm{kg}^{-1}$ (Figure $3 \mathrm{C}$ and D). Meanwhile, cortisol levels decreased with increasing YE supplementation levels in a dose-dependent manner.

Table 5. Immunological parameters and cortisol levels of European seabass (Dicentrarchus labrax) fed diets supplemented with different levels of Yucca schidigera extract $\left(\mathrm{g} \mathrm{kg}^{-1}\right)(\mathrm{n}=3$; mean $\pm \mathrm{SE})$

\begin{tabular}{l|c|c|c|c}
\hline \multirow{2}{*}{\multicolumn{1}{c}{ Treatments }} & \multicolumn{4}{c}{ Yucca extract levels $\left(\mathrm{g} \mathrm{kg}^{-1}\right)$} \\
\cline { 2 - 5 } & 0.00 & 0.25 & 0.50 & 1.00 \\
\hline Total protein $\left(\mathrm{g} \mathrm{dL}^{-1}\right)$ & $4.30 \pm 0.17 \mathrm{bc}$ & $3.85 \pm 0.17 \mathrm{c}$ & $4.67 \pm 0.12 \mathrm{~b}$ & $5.08 \pm 0.11 \mathrm{a}$ \\
Albumin $\left(\mathrm{g} \mathrm{dL}^{-1}\right)$ & $2.57 \pm 0.18 \mathrm{a}$ & $1.96 \pm 0.18 \mathrm{~b}$ & $2.51 \pm 0.12 \mathrm{a}$ & $2.64 \pm 0.10 \mathrm{a}$ \\
Globulin ( $\left.\mathrm{g} \mathrm{dL}^{-1}\right)$ & $1.73 \pm 0.19 \mathrm{~b}$ & $1.89 \pm 0.19 \mathrm{~b}$ & $2.16 \pm 0.12 \mathrm{ab}$ & $2.44 \pm 0.12 \mathrm{a}$ \\
Alpha globulin $\left(\mathrm{g} \mathrm{dL}^{-1}\right)$ & $0.41 \pm 0.02 \mathrm{~d}$ & $0.47 \pm 0.01 \mathrm{c}$ & $0.55 \pm 0.02 \mathrm{~b}$ & $0.78 \pm 0.02 \mathrm{a}$ \\
Beta globulin $\left(\mathrm{g} \mathrm{dL}^{-1}\right)$ & $0.30 \pm 0.01 \mathrm{~d}$ & $0.39 \pm 0.01 \mathrm{c}$ & $0.53 \pm 0.02 \mathrm{~b}$ & $0.68 \pm 0.01 \mathrm{a}$ \\
Gamma globulin $\left(\mathrm{g} \mathrm{dL}^{-1}\right)$ & $0.59 \pm 0.01 \mathrm{~d}$ & $0.76 \pm 0.01 \mathrm{c}$ & $0.87 \pm 0.03 \mathrm{~b}$ & $0.96 \pm 0.05 \mathrm{a}$ \\
Lysozyme $\left(\mathrm{U} \mathrm{mg}^{-1} \mathrm{protein}\right)$ & $0.10 \pm 0.01 \mathrm{~b}$ & $0.12 \pm 0.03 \mathrm{~b}$ & $0.59 \pm 0.06 \mathrm{a}$ & $0.49 \pm 0.03 \mathrm{a}$ \\
Cortisol (Pg mL & $457.0 \pm 9.95 \mathrm{a}$ & $380.0 \pm 6.95 \mathrm{~b}$ & $280.43 \pm 2.01 \mathrm{c}$ & $266.43 \pm 4.01 \mathrm{~d}$ \\
\hline
\end{tabular}

Means in the same row bearing different letters differ significantly $(\mathrm{P} \leq 0.05)$.

\section{Revenue}

The production cost of feeding D. labrax fingerlings with diets supplemented with different levels of YE was significantly reduced for $\mathrm{YE}_{0.5}$ and $\mathrm{YE}_{1}$ (by $23.34 \%$ and $32.72 \%$, respectively) compared to that of the control (Figure 4). 
A
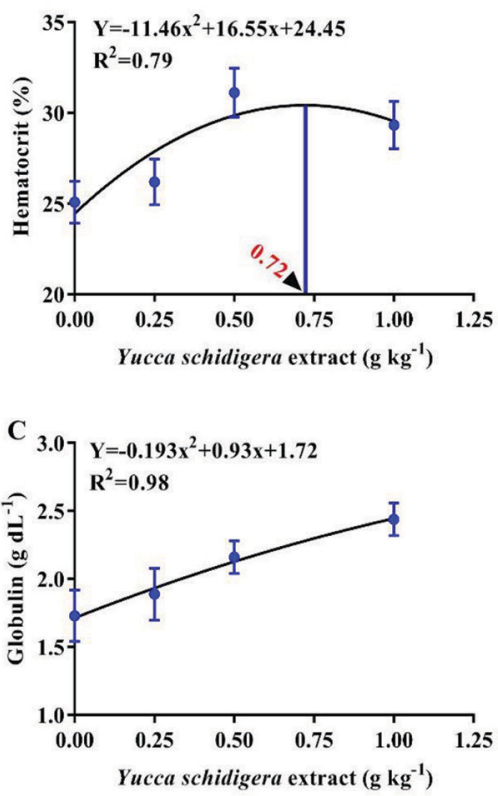

B

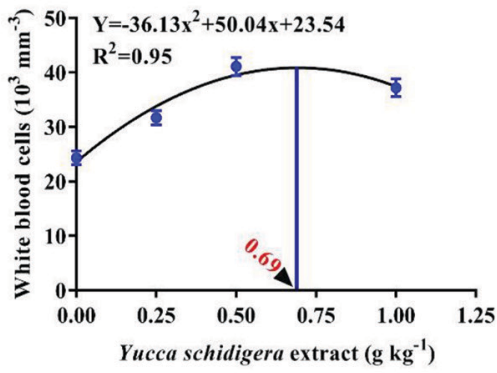

D

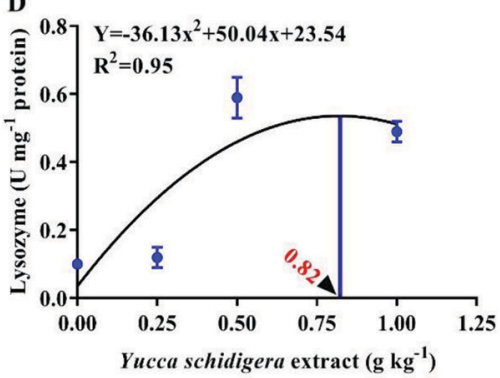

Figure 3. Polynomial second-order regression curve of different hematological and immunological parameters of European seabass (Dicentrarchus labrax) fingerlings fed diets supplemented with Yucca schidigera extract $\left(\mathrm{g} \mathrm{kg}^{-1}\right)$

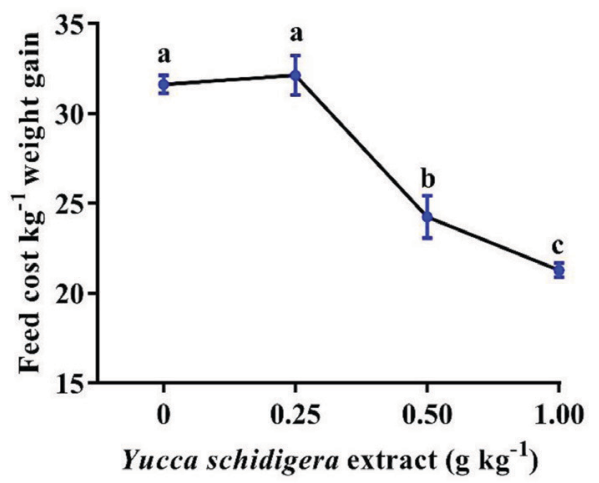

Figure 4. Cost of feed to obtain $1 \mathrm{~kg}$ live weight of European seabass (Dicentrarchus labrax) fingerlings fed diets supplemented with different levels of Yucca schidigera extract $\left(\mathrm{g} \mathrm{kg}^{-1}\right.$ diet) (mean $\left.\pm \mathrm{SE}\right)$

\section{Discussion}

Reducing the environmental footprint of animal protein production is a global concern parallel to sustainable livestock development (Patra, 2012; Adegbeye et al., 
2019). Consequently, improving protein metabolism and controlling nitrogenous wastes in aquaculture systems are necessary to meet effluent standards (Kelly and Kohler, 2003) and maximize protein utilization which is the most expensive feed component (Goda et al., 2019). In aquaculture systems, particularly those involving carnivorous marine species, the use of high-protein diets increases the excretion of nitrogenous wastes (Efole-Ewoukem et al., 2013). Therefore, supplementing the diet with plants or their extracts may be a practical strategy in aquaculture nutrition to minimize ammonia production and promote growth and immunity (Awad and Awaad, 2017; Mansour et al., 2017, 2018 a; Adegbeye et al., 2019; Kesbiç et al., 2020).

The present study showed that dietary YE supplementation significantly decreased ammonia levels in fish-rearing water in a dose-dependent manner. Similarly, YE supplementation $\left(0.5\right.$ and $\left.1 \mathrm{~g} \mathrm{~kg}^{-1}\right)$ reduced ammonia excretion and increased the final weight of cultured channel catfish (Ictalurus punctatus) (Kelly and Kohler, 2003). In addition, dietary YE successfully controlled ammonia nitrogen levels in rearing waters of different aquatic animal species, including white shrimp (Litopenaeus vannamei), striped catfish (Pangasianodon hypophthalmus), and Nile tilapia (Oreochromis niloticus) (Güroy et al., 2014; Yang et al., 2015; Hassan et al., 2017). The YE addition to fish-rearing water decreased ammonia levels and improved water quality (Santacruz-Reyes and Chien, 2009; Fayed et al., 2019). This reduction in ammonia levels could be due to the adsorption of ammonia by active surface components of YE, including steroidal saponins and glycol (Cheeke, 2000; Ayasan et al., 2005), hence it will be more available for synthesis of another nitrogenous compound (Hertrampf and Piedad-Pascual, 2000). Controlling ammonia excretion may facilitate aquaculture intensification with decreasing nutrient losses to the environment, thereby lowering the occurrence of large point source of environmental pollution (Sutton et al., 2013).

In this study, FBW of the treated fish was improved by $8.16 \%, 26.02 \%$, and $36.98 \%$ with $\mathrm{YE}_{0.25}, \mathrm{YE}_{0.5}$, and $\mathrm{YE}_{1}$, respectively, compared to that of the control fish. These results are consistent with those of I. punctatus fed YE-supplemented diets at a level of $1 \mathrm{~g} \mathrm{~kg}^{-1}$, which gained significantly more weight (Kelly and Kohler, 2003). Moreover, the growth performance of $O$. niloticus improved significantly when fed a diet supplemented with YE (El-Saidy and Gaber, 2004), and YE at a level of $0.75 \mathrm{mg} \mathrm{kg}^{-1}$ improved the growth of fish fed plant protein-based diets to a level equal to that of fish fed fishmeal-based diets (Gaber, 2006). In addition, the growth of striped catfish (P. hypophthalmus) improved significantly with dietary supplementation of YE and Y. saponaria extracts (Güroy et al., 2014). Furthermore, the positive effects of YE on growth have been confirmed in several animal species, including white shrimp (Yang et al., 2015), Arbor Acres broilers (Su et al., 2016), and growing rabbits (Amber et al., 2004; Földešiová et al., 2017).

Regarding feed and protein utilization, our findings showed an improvement in feed intake in YE-supplemented groups, indicating that YE did not negatively affect diet palatability. Moreover, the increased feed intake noted in the present study may due to hormonal regulation by YE (Kucukkurt and Dundar, 2013), whereas YE increased leptin and insulin levels in the plasma of treated rats. Furthermore, 
FCR improved significantly with YE supplementation at higher levels (by 39\% with $\mathrm{YE}_{0.5}$ and $55 \%$ with $\mathrm{YE}_{1}$ ) compared to that with the control treatment. Protein efficiency ratio also increased significantly by $43 \%$ and $70 \%$ in the groups fed $\mathrm{YE}_{0.5}$ and $\mathrm{YE}_{1}$, respectively. Likewise, $\mathrm{YE}$ improved feed and protein utilization in channel catfish (Kelly and Kohler, 2003), Nile tilapia (El-Saidy and Gaber, 2004; Gaber, 2006), striped catfish (Güroy et al., 2014), white shrimp (Yang et al., 2015), broiler chickens, and rabbits (Amber et al., 2004; Su et al., 2016; Földešiová et al., 2017). Nitrogen utilization improved by $24.3 \%$ in rabbits fed a diet supplemented with YE (0.25 $\left.\mathrm{g} \mathrm{kg}^{-1}\right)$ compared to that in rabbits fed a control diet (Amber et al., 2004). In contrast, in the present study, no improvement in PER to the same level was noted with YE supplementation at $0.25 \mathrm{~g} \mathrm{~kg}^{-1}$, although PER improved with higher levels of YE supplementation; this may be attributed to differences in experimental animals and stark differences in digestive system anatomy and physiology.

The improvement of protein utilization with increasing YE level in the present study may be attributed to enhance activities of digestive enzymes associated with YE supplementation (Liu et al., 2005). Additionally, an increase in PER could be due to the reduction in ammonia nitrogen levels in the rearing water as a result of reduced excretion of ammonia in fish fed diets supplemented with YE (Figure 1). In parallel with the present findings, there was a reduction in ammonia excretion and fecal nitrogen concentrations with YE, as reported in I. punctatus (Kelly and Kohler, 2003). Moreover, YE supplementation reduced blood urea and cecal ammonia concentrations in rabbits (Amber et al., 2004), possibly reflecting the strong adsorption capacity of YE active components for volatile compounds, including ammonia and hydrogen sulfide (Cheeke, 2000).

Furthermore, improvements in growth performance, FCR, and PER in the present study may be attributed to the active components of YE including steroidal saponins and reservatol (Cheeke, 2000; Ayasan et al., 2005). The presence of steroidal saponins can improve nutrient absorption (Yang et al., 2015) by altering the enterocyte membrane structure, reducing surface tension (Goetsch and Owens, 1985), and increasing the permeability of intestinal membranes to dietary nutrients (Francis et al., 2002). In addition, YE can improve the intestinal wall integrity by increasing thickness of the intestinal mucosa, preventing the invasion of certain types of viruses, improving the animal's immunity, and suppressing intestinal bacterial growth (Huang et al., 2005).

In the present study, the increase in $\mathrm{RBC}, \mathrm{Hb}, \mathrm{Ht}$, and $\mathrm{WBC}$ values indicated an improvement of hematopoietic organs activities and health status. In striped catfish, P. hypophthalmus, dietary supplemented with YE at a level of $0.15 \%$ significantly improved PCV (\%), Hb, and lymphocyte percentage compared with the non-supplemented diet (Güroy et al., 2014). Additionally, increasing YE addition in the liquid form to rearing water significantly improved the hematological and physiological status of seabass fingerlings (Fayed et al., 2019). However, increasing YE supplementation level to $1 \mathrm{~g} \mathrm{~kg}^{-1}$ tended to decrease some hematological and immunological parameters in the present findings, as indicated by the polynomial second-order regression fit models with curves peak in the range of $0.72-0.82 \mathrm{~g} \mathrm{YE} \mathrm{kg}^{-1}$. Therefore, the optimum YE supplementation level should not exceed $1 \mathrm{~g} \mathrm{~kg}^{-1}$ in seabass 
diets. Limitations such as this may be attributed to increasing saponin levels in supplemented diets, which may affect the function of specific cells and increase hemolysis, leading to improper functioning of certain fish organs (Tidwell et al., 1992).

Yucca extract supplementation improved innate immune responses with increasing total protein, albumin, globulin, and globulin fraction (alpha, beta and gamma globulin) levels and lysozyme activity in YE-supplemented group. The plasma total protein is an indicator of general health status of the animal reflecting the functions of liver, kidney, and the immune system (Patra et al., 2011). The major components of total protein are globulin and albumin, therefore improving protein synthesis in the liver could improve the globulin level. The globulin fraction consists of alpha and beta acting as acute-phase proteins and gamma globulin fraction level represents the antibody (Jolles et al., 2014). Accordingly, increasing the globulin fraction in the present study means an improvement in immune response with dietary YE supplementation.

In agreement with the present findings, YE supplementation increased non-specific immune defenses in L. vannamei (Yang et al., 2015). Moreover, saponins as the main components of YE could stimulate cytokine secretion, which in turn regulates humoral and cellular immune responses (Palatnik de Sousa et al., 2004; Song and $\mathrm{Hu}, 2009$ ). Saponin supplementation maximized the efficacy of immunization in chickens and increased protection against challenge (Berezin et al., 2010). Furthermore, YE promoted leptin hormone secretion, which participates in controlling the immune system function in several animals (Kucukkurt and Dundar, 2013).

In addition, YE has been shown to exhibit a wide variety of immunological characteristics (Mimaki and Sashida, 1996), such as anti-inflammatory, antiallergic, antiviral, and molluscicidal activities (Hassan et al., 2017). Moreover, YE improved antioxidant balance in broiler chickens (Su et al., 2016) and showed a strong radical scavenging activity (Sobia et al., 2013). Resveratrol as one of the YE components can protect animals from diseases because of its antioxidant, antiviral, antiinflammatory, and iNOS inhibitory properties (Piacente et al., 2005). In addition, YE showed a potential stress relief effect in biological systems (Cigerci et al., 2009; Ince et al., 2013). In this study, cortisol levels were significantly reduced with YE supplementation in a dose-dependent manner.

Finally, the major proportion of operating costs for aquaculture projects arises from the feed. Therefore, increasing feed utilization or decreasing feed costs would help in maximizing the revenue margin (Goda et al., 2019; Khalil et al., 2019; Allam et al., 2020). In this study, dietary supplementation with higher doses of YE reduced the cost of fish production (by $23.34 \%$ with $\mathrm{YE}_{0.5}$ and by $32.72 \%$ with $\mathrm{YE}_{1}$ ). In the same vein, the increasing of dietary supplementation levels, including prebiotics, probiotics, and symbiotics in fresh and marine culture fish diets can increase revenue (Azevedo et al., 2015; Khalil et al., 2019).

\section{Conclusion}

The present study demonstrated multiple benefits of dietary YE supplementation in terms of water quality, zootechnical performance, health status, and revenue. Yucca extract supplementation reduced ammonia nitrogen levels in fish-rearing wa- 
ter and improved growth performance, FCR, and PER of the cultured fish in a dosedependent manner, with a maximum response noted at $1 \mathrm{~g} \mathrm{YE} \mathrm{kg}^{-1}$ diet as confirmed by quadratic regression models. In addition, there were significant improvements in hematological parameters and innate immune status with increasing dietary YE levels. In conclusion, dietary YE supplementation may contribute to the optimal water use and cleaner production in the aquaculture industry. However, the long-term effect of YE supplementation needs more investigation.

\section{Acknowledgments}

The authors gratefully acknowledge the staff of the Fish and Animal Production Department, Faculty of Agriculture, Alexandria University, Egypt for their help with the analysis in this study. Also, we appreciate the substantial contribution of staff members of the College of Agriculture and Food Sciences, King Faisal University, Saudi Arabia for their contribution to fulfil this work.

\section{Conflicts of Interest}

There is no conflict of interests among authors and organizations.

\section{References}

A c a r Ü. (2018). Effects of diet supplemented with ethanolic extract of propolis on growth performance, hematological and serum biochemical parameters and disease resistance of Mozambique tilapia (Oreochromis mossambicus) against Streptococcus iniae. Aquaculture, 495: 339-344.

A c a r Ü., K e s b i ç O.S., İ n a n a n B.E., Y $11 \mathrm{~m}$ a z S. (2019). Effects of dietary Bergamot (Citrus bergamia) peel oil on growth, haematology and immune response of European sea bass (Dicentrarchus labrax) juveniles. Aquacult. Res., 50: 3305-3312.

A degbeye M.J., Elghandour M.M., Monroy J.C., A begunde T.O., S a le m A.Z., B arb a b o s a-P 1 i e g o A., F a n i y i T.O. (2019). Potential influence of Yucca extract as feed additive on greenhouse gases emission for a cleaner livestock and aquaculture farming - a review. J. Clean. Prod., 239: 118074.

A 11 a m B.W., K hali 1 H.S., M a n sou r A.T., S rour T.M., O mar E.A., Nour A.A.M. (2020). Impact of substitution of fish meal by high protein distillers dried grains on growth performance, plasma protein and economic benefit of striped catfish (Pangasianodon hypophthalmus). Aquaculture, 517: 734-742.

A 1 ta n O., Korkut A.Y. (2010). Effects of temperature and dietary carbohydrate level to growth performance and feed digestibility of European sea bass juveniles (Dicentrarchus labrax). Bulg. J. Agric. Sci., 16: 775-782.

A m b e r K., A k o u t H.M., H a m e d R.S. (2004). Effect of feeding diets containing yucca extract or probiotic on growth, digestibility, nitrogen balance and caecal microbial activity of growing New Zealand White rabbits. Proc. 8th World Rabbit Congress, 7-10.09.2004, Puebla, Mexico.

AOAC (2000). International Official Methods of Analysis, 17th edition. Association of Official Analytical Chemists (AOAC). Arlington, Virginia, USA.

A.P.H.A. (1998). Standard Methods for the Examination of Water and Wastewater, 20th ed. American Public Health Association, American Water Works Association and Water Environment Federation, Washington DC, USA.

A ubin J., Callier M., Rey-Valette H., Mathe S., Wilfart A., Legendre M., Slembrouck J., Carus o D., Chi a E., Mas s on G. (2019). Implementing ecological intensification in fish farming: definition and principles from contrasting experiences. Rev. Aquacult., 11: $149-167$. 
Aw a d E., Aw a d A. (2017). Role of medicinal plants on growth performance and immune status in fish. Fish Shellfish Immunol., 67: 40-54.

Ay a s an T., Yurts even S., B a y lan M., C a n o gullari S. (2005). The effects of dietary Yucca schidigera on egg yield parameters and egg shell quality of laying Japanese quails (Coturnix coturnix japonica). Int. J. Poultry Sci., 4: 159-162.

Azevedo R.V. de., Fosse Filho J.C., Cardoso L.D., da Cruz Mattos D., Vazquez Vidal Jr. M., de Andrade D.R. (2015). Economic evaluation of prebiotics, probiotics and symbiotics in juvenile Nile tilapia. Rev. Cienc. Agron., 46: 72-79.

B erezin V., Bogoyavlenskyi A., Khudiakova S., A lexuk P., Omirta eva E., Zait c e v a I. (2010). Immunostimulatory complexes containing Eimeria tenella antigens and low toxicity plant saponins induce antibody response and provide protection from challenge in broiler chickens. Vet. Parasitol., 167: 28-35.

B es son M., A ubin J., Komen H., Poelman M., Quillet E., Vandeputte M., Van Are n d o n k J., D e B o e r I. (2016). Environmental impacts of genetic improvement of growth rate and feed conversion ratio in fish farming under rearing density and nitrogen output limitations. J. Clean. Prod., 116: 100-109.

Cas te 11 J.D., Tiew es K. (1980). Report of the EIFAC, IUNS and ICES working group on the standardization of methodology in fish research, Hamburg, FRG, 21-23.03.1979. IFAC Tech. Pap., 24.

Ch e e k e P.R. (2000). Actual and potential applications of Yucca schidigera and Quillaja saponaria saponins in human and animal nutrition. J. Anim. Sci., 77: 1-10.

Cigerci I.H., Fidan A.F., Konuk M., Yuksel H., Kucukkurt I., Eryavuz A., S ozbi li $\mathrm{r}$ N.B. (2009). The protective potential of Yucca schidigera (Sarsaponin $30^{\circledR}$ ) against nitrite-induced oxidative stress in rats. J. Nat. Med., 63: 311-317.

D un c a n D. (1955). Multiple range and multiple F test. Biometric, 11: 1-42.

Efole-Ewoukem T., Has souna M., Robin P., Mikolasek O., Aubin J., Ombred a n e D. (2013). Estimation test of gaseous emissions from fishponds with contrasted inputs. In: Emissions of gas and dust form livestock, Hassouna M., Guingand N. (eds.). IFIP e Institut Technique du Porc. HAL Archives-Ouvertes, Saint-Malo, France, pp. 35-39.

E 1 - S a i d y D.M.S., G a b e r M.M.A. (2004). Effect of Yucca schidigera on water quality and growth performance of Nile tilapia (O. niloticus L) fingerlings. Egypt. J. Aquat. Biol. Fish., 8: 33-50.

Eroldogan O.T., Kumlu M., Aktas M. (2004). Optimum feeding rates for European sea bass (Dicentrarchus labrax L.) reared in seawater and freshwater. Aquacult. Nutr., 231: $501-515$.

F a y e d W.M.A., Kh a 1 i 1 R.H., S a 11 a m G.R., M a n s o u r A.T., E 1 - k h a y a t a B.K., O m a r E.A. (2019). Estimating the effective level of Yucca schidigera extract for improvement of the survival, haematological parameters, immunological responses and water quality of European seabass juveniles (Dicentrarchus labrax). Aquacult. Rep., 15: 100208.

Földešiová M., B aláži A., Chrastinová L', Pivko J., Kotwica J., Harrath A.H., Chrenek P., S irotkin A.V. (2017). Yucca schidigera can promote rabbit growth, fecundity, affect the release of hormones in vivo and in vitro, induce pathological changes in liver, and reduce ovarian resistance to benzene. Anim. Reprod. Sci., 183: 66-76.

Fran c is G., K e r e m Z., M a k k a r H.P.S., B e c k e r K. (2002). The biological action of saponins in animal systems: a review. Brit. J. Nutr., 88: 587-605.

Gaber M.M. (2006). The effects of plant-protein-based diets supplemented with yucca on growth, digestibility, and chemical composition of Nile tilapia (Oreochromis niloticus L.) fingerlings. J. World Aquacult. Soc., 37: 74-81.

GAFRD (2017). Fish statistic year book, 26th ed., General authority for fisheries resources development, Ministry of Agriculture and Land Reclamation, Egypt.

God a A.A.S., S rour T.M., O m a r E., Man s ou r A.T., B arom h M.Z., M oh a m ed S.A., E1 Haroun E., Davies S.J. (2019). Appraisal of a high protein distiller's dried grain (DDG) in diets for European sea bass, Dicentrarchus labrax, fingerlings on growth performance, haematological status and related gut histology. Aquacult. Nutr., 25: 808-816.

G o e t s c h A.L., O w e n s F.N. (1985). Effects of sarsaponin on digestion and passage rates in cattle fed medium to low concentrate. J. Dairy Sci., 68: 2377-2384. 
Gomez-S anchez C., Milew i ch L., Holland O.B. (1977). Radioiodinated derivatives for steroid radioimmunoassay. Application to the radioimmunoassay of cortisol. J. Lab. Clin. Med., 89: 902-909.

Gornal A.C., B a rdaw ill C.J., D a vid M.M. (1949). Determination of serum proteins by means of the biuret reaction. J. Biol. Chem., 177: 751-766.

Gü ro y B., M a n to ğ lu S., K a y a 11 S., Ş a h in İ. (2014). Effect of dietary Yucca schidigera extract on growth, total ammonia-nitrogen excretion and haematological parameters of juvenile striped catfish Pangasianodon hypophthalmus. Aquacult. Res., 45: 647-654.

H a s s a n M.A., Yu s u f M.S., B a d r a n M.F., S h Gri e s h A., Z i d a n R.A. (2017). Effect of Yucca shidigera extract and or exogenous enzymes on nitrogenous compounds in Nile tilapia aquaculture. Int. J. Agric. Sci. Vet. Med., 5: 55-71.

H e a d on D.R., D a w s on K.A. (1990). Yucca extract controls atmospheric ammonia levels. Feed Stuffs, 62: 6-15.

Hertram p f.W., P i e d a d-P a s c a l F. (2000). Yucca schidigera extract, Handbook on Ingredients for Aquaculture Feeds. Springer, pp. 551-555.

Hristov A.N., Mc Allister T.A., van Herk F.H., Cheng K.-J., Newbold C.J., Che e k e P.R. (1999). Effect of Yucca schidigera on ruminal fermentation and nutrient digestion in heifers. J. Anim. Sci., 77: 2554-2563.

H u a n g H.Q., Z heng G.H., C h en F.R. (2005). Yucca schidigera plant - a natural multi-functional feed additive. Anim. Sci. Abroad, 32: 61-64.

Ihara H., Toya N., Kakinoki T., Tani A., Aoki Y., Hashizume N., Inada Y., Nanb a S., Ur a y a m a T., Yos hid a M. (2001). Reference ranges for serum protein fractions as determined by capillary zone electrophoresis. Seibutsu Butsuri Kagaku, 45: 69-74.

Ince S., K u cuk kurt I., Turkmen R., D e mire l H.H., S e ver E. (2013). Dietary Yucca schidigera supplementation reduces arsenic-induced oxidative stress in Swiss albino mice. Toxicol. Ind. Health, 29: 904-914.

Jolles S., Borrell R., Zouwail S., Heaps A., Sharp H., Moody M., Selwood C., Will i a m s P., Phill i p s C., H o o d K. (2014). Calculated globulin (CG) as a screening test for antibody deficiency. Clin. Exp. Immunol., 177: 671-678.

K e 11 y A.M., K o h 1 e r C.C. (2003). Effects of Yucca schidigera extract on growth, nitrogen retention, ammonia excretion, and toxicity in channel catfish, Ictalurus punctatus and hybrid tilapia, Oreochromis mossambicus $\times$ O. niloticus. J. World Aquacult. Soc., 34: 156-161.

K e s b i ç O.S., P a rrin o V., A c a r Ü., Y i 1 m a z S., P a ro G.L., F a z i o F. (2020). Effects of Monterey cypress (Cupressus macrocarpa Hartw) leaf essential oil as a dietary supplement on growth performance and haematological and biochemical parameters of common carp (Cyprinus carpio L.). Ann. Anim. Sci., 4: 1411-1426.

K h a 1 i 1 R.H., S a d T.T., R a g a b H.M.G., M o h a m m e d R.A.E.A. (2015). Effect of Yucca schidigera on water quality of Nile Tilapia fingerlings. J. Am. Sci., 11: 83-88.

Khalil H.S., Man s o u r A.T., Goda A.M.A., O m a r E.A. (2019). Effect of selenium yeast supplementation on growth performance, feed utilization, lipid profile, liver and intestine histological changes, and economic benefit in meagre, Argyrosomus regius, fingerlings. Aquaculture, 501: $135-143$.

K u c u k k urt I., D und a r Y. (2013). Effects of dietary Yucca schidigera supplementation on plasma leptin, insulin, iodated thyroid hormones and some biochemical parameters in rats. Rev. Med. Vet., 164: 362-367.

Kucukkurt I., Akkol E.K., Karabag F., Ince S., Süntar I., Eryavuz A., Sözbilir N.B. (2016). Determination of the regulatory properties of Yucca schidigera extracts on the biochemical parameters and plasma hormone levels associated with obesity. Rev. Bras. Farmacogn., 26: 246-250.

L i u C.L., S u n H.X., L i C.S., L i u Y.B. (2005). The application of sarsaponin on improving the environment of barn and discussion of mechanism. Sys. Sci. Comp. Stud. Argi., 3: 14-16.

Man s our A.T., G od a A.A., O mar E.A., Kh a 1 i 1 H.S., E s t e b a n M.A. (2017). Dietary supplementation of organic selenium improves growth, survival, antioxidant and immune status of meagre, Argyrosomus regius, juveniles. Fish Shellfish Immunol., 68: 516-524.

Man s our A.T., O mar E.A., S rour T.M., You s e f M.I. (2018 a). Effect of three natural phyto- 
chemicals supplementation on growth performance, testosterone level and feed utilization of Nile tilapia (Oreochromis niloticus). Aquacult. Nutr., 24: 408-415.

Mans our A.T., Mia o L., Espinos a C., García-Beltrán J.M., Francisco D.C.C., Es t e b a n M.Á. (2018 b). Effects of dietary inclusion of Moringa oleifera leaves on growth and some systemic and mucosal immune parameters of seabream. Fish Physiol. Biochem., 44: 1223-1240.

Mimaki Y., S a shida Y. (1996). Steroidal saponin from the Liliaceae plants and their biological activities, pp. 102-109. In: Saponin Used in Traditional and Modern Medicine, G.R. Waller, K. Yamasakly (eds.). Adv. Exp. Med. Biol., 404, Plenum Press, New York, 606 pp.

National Research Council (2011). Nutrient requirements of fish and shrimp. National Academies Press, Washington, DC, USA.

Palatnik de Sousa C., Santos W., Casas C., Paraguai de Souza E., Tinoco L., d a S i lv a B. (2004). Protective vaccination against murine visceral leishmaniasis using aldehydecontaining Quillaja saponaria sapogenins. Vaccine, 22: 2470-2479.

P atra A.K. (2012). An overview of antimicrobial properties of different classes of phytochemicals. In: Dietary Phytochemicals and Microbes, Patra A.K. (ed.). Springer, New York, USA, pp. 1-32.

P a tr a R., R a u tr a y A.K., S w a r u p D. (2011). Oxidative stress in lead and cadmium toxicity and its amelioration. Vet. Med. Int., 2011: 1-9.

P i a c e nte S., P izza C., O les zek W. (2005). Saponins and phenolics of Yucca schidigera Roezl: chemistry and bioactivity. Phytochem. Rev., 4: 177-190.

R e in h old R.R. (1953). Determination of serum albumin. Clin. Chem., 21: 1370-1372.

S a n t a c ru z-R e y e s R.A., C h i e n Y.-H. (2009). Efficacy of Yucca schidigera extract for ammonia reduction in freshwater: Effectiveness analysis and empirical modeling approach. Aquaculture, 297 : $106-111$.

S a n t a c ru z- R e y e s R.A., Ch i e n Y.-H. (2010). Ammonia reduction in seawater by Yucca schidigera extract: efficacy analysis and empirical modelling. Aquacult. Res., 41: 1221-1228.

S a r k a r S.K. (1999). Role of plant glycocomponents (de-odorase) on freshwater prawn, Macrobrachium malcolmsonii in ponds. J. Environ. Biol., 20: 299-301.

S ob i a A., Zubair M., R a s o ol N., Mansha A., A njum F., Mun aw ar lqual E. (2013). Antioxidant, antibacterial, antifungal activities and phytochemical analysis of dagger (Yucca aloifolia) leaves extracts. J. Med. Plant Res., 7: 243-249.

S ong X., Hu S. (2009). Adjuvant activities of saponins from traditional Chinese medicinal herbs. Vaccine, 27: 4883-4890.

S u J.-L., S h i B.-L., Z h a ng P.-F., S u n D.-S., L i T.-Y., Ya n S.-M. (2016). Effects of yucca extract on feed efficiency, immune and antioxidative functions in broilers. Braz. Arch. Biol. Technol., 59: e16150035.

Sutton M.A.B., Howard C.M., Bekunda M., Grizzetti B., de Vries W., van Arendonk J., Grinsven H.J.M., Abrol Y.P., Adhy a T.K., Billen G., Davidson E.A., Datta A., Diaz R., Eris man J.W., Liu X.J., O en e ma O., Palm C., R a ghuram N., Re is S., Scholz R.W., S ims T., Westhoek H., Zhang F.S. (2013). Our nutrient world: the challenge to produce more food and energy with less pollution. The Global Partnership on Nutrient Management and the International Nitrogen Initiative, Centre for Ecology and Hydrology (Edinburgh), UK.

Swa in P., Dash S., S ahoo P., Routray P., S ahoo S., Gupta S., Meher P., S a rangi N. (2007). Non-specific immune parameters of brood Indian major carp Labeo rohita and their seasonal variations. Fish Shellfish Immunol., 22: 38-43.

Tenon M., Feuillère N., Roller M., Birtić S. (2017). Rapid, cost-effective and accurate quantification of Yucca schidigera Roezl. steroidal saponins using HPLC-ELSD method. Food Chem., 221: 1245-1252.

Tidwe 11 J.H., Webster C.D., C 1 ark J.A., Yan c e y D.H. (1992). Effects of Yucca schidigera extract on water quality and fish growth in recirculating-water aquaculture systems. The Progressive Fish-Culturist, 54: 196-201.

U.S. EPA (1989). Ambient Water Quality Criteria for Ammonia (Saltwater). Environmental Protection Agency 440/5-88-004. National Technical Information Service (NTIS), Springfield, VA.

Van-Kampen E.J., Zij 1 s tra W.G. (1961). Standardization of hemoglobinometry. Clin. Chim. Acta, 6: 438-544. 
Yang Q.-H., Tan B.-P., D ong X.-H., Ch i S.-Y., Li u H.-Y. (2015). Effects of different levels of Yucca schidigera extract on the growth and nonspecific immunity of Pacific white shrimp (Litopenaeus vannamei) and on culture water quality. Aquaculture, 439: 39-44.

Received: 2 X 2020

Accepted: 20 I 2021 